\title{
ОЦЕНКА ВОЗДЕЙСТВИЯ УГОЛЬНОГО РАЗРЕЗА ООО «РАЗРЕЗ "БЕРЕЗОВСКИЙ" ॥ НА ОКРУЖАЮЩИЕ ЗЕМЛИ СЕЛЬСКОХОЗЯЙСТВЕННОГО НАЗНАЧЕНИЯ
}

\section{Анастасия Александровна Пичугова}

Сибирский государственный университет геосистем и технологий, 630108, Россия, г. Новосибирск, ул. Плахотного, 10, обучающийся, тел. (999)446-74-35, e-mail: pichugova_ans@mail.ru

Представлены результаты изучения влияния работы «Разреза «Березовский» на земли сельскохозяйственного назначения, окружающие предприятие. В статье рассматриваются основные загрязняющие вещества, воздействующие на атмосферу при осуществлении намечаемой деятельности на предприятии ООО «Разрез «Березовский». Обсуждаются мероприятия и расчеты для определения содержания вредных веществ в почвах на окружающих территориях, где земли относятся к категории земель сельскохозяйственного назначения.

Ключевые слова: загрязняющие вещества, выбросы, земли сельскохозяйственного назначения, категории земель

\section{ASSESSMENT OF THE IMPACT OF THE BEREZOVSKY COAL MINE ON THE SURROUNDING AGRICULTURAL LAND}

\section{Anastasiya A. Pichugova}

Siberian State University of Geosystems and Technologies, 10, Plakhotnogo St., Novosibirsk, 630108, Russia, Student, phone: (999)446-74-35, e-mail: pichugova_ans@mail.ru

The results of studying the impact of the Berezovsky Section on agricultural land surrounding the enterprise are presented. The article deals with the main pollutants that affect the atmosphere during the implementation of the planned activities at the enterprise LLC "Berezovsky" Section". Measures and calculations for determining the content of harmful substances in soils in surrounding areas where land is classified as agricultural land are discussed.

Keywords: pollutants, emissions, agricultural land, land categories

\section{Введение}

Состояние угледобывающей отрасли России в последнее десятилетие характеризуется стабильным ростом как объемов добычи, так и объемов экспорта угля. На сегодняшний день угледобывающая промышленность достигла определенных успехов в модернизации горного хозяйства, вырос уровень механизации, оптимизации производства, повысился уровень безопасности ведения горных работ. В настоящее время негативное воздействие угледобывающих предприятий на окружающую среду принято ассоциировать в основном с выбросом твердых веществ (пыли) в атмосферу, большими объемами сброса сточных вод в водные объекты, образованием и размещением крупнотоннажных отходов. Однако разработка угольного месторождения также оказывает непосредственное влияние на недра (включая грунты и горные породы), подземные воды, почвы, растительный и животный мир. Т.е. можно сделать вывод, что при разработке месторождения полезного ископаемого негативному воздействию подвергаются все компоненты окружающей среды. 
Цель исследований: изучить влияние работы «Разреза «Березовский» на земли сельскохозяйственного назначения, окружающие предприятие.

\section{Объекты и методы}

Объектом исследований являлся участок «Разрез Южный» ООО «Разрез «Березовский». По административному делению лицензионный участок расположен на территории Прокопьевского и Новокузнецкого муниципальных районов Кемеровской области. В границах участка населённых пунктов нет. Города Новокузнецк и Прокопьевск расположены в 20 км к востоку и в 10 км к северу от лицензионного участка соответственно. В непосредственной близости от участка «Березовский Южный» расположены поселок Новый Путь и село Березово. Поселок Новый путь расположен на расстоянии 2,4 км к западу, а с. Березово на расстоянии 56 м к югу от лицензионных границ участка. В связи с близостью расположения жилой застройки от лицензионных границ участка (до с. Березово -56 м) отработка участка была предусмотрена в 2 этапа: первая очередь - ведение открытых горных работ на расстоянии 1000 м от с. Березово; вторая очередь - переселения жилой застройки с. Березово за границы нормируемых территорий и доработка месторождения в границе лицензии.

\section{Результаты и обсуждение}

Основными постоянно действующими источниками загрязнения атмосферного воздуха на участке открытых работ «Березовский Южный» (вторая очередь) ООО «Разрез «Березовский» является участок открытых горных работ, транспортирование горной массы , склады угля.. В атмосферный воздух выделяется пыль при работе экскаваторов (погрузка угля и вскрышных пород), бульдозеров (зачистка площадок), буровых станков и другого оборудования.

К источникам периодического действия относятся взрывные работы. В результате взрыва происходит залповый выброс вредных веществ и образуется пылегазовое облако. После взрыва происходит остаточное газовыделение из взорванной горной массы. Воздействие на атмосферу при массовом взрыве носит кратковременный характер. Продолжительность взрыва достигает 5 секунд. Рассеивание загрязняющих веществ, образованных в результате взрыва, длится не более 20 мин.

Расчеты выбросов загрязняющих веществ выполнены в соответствии с методическими материалами, представленными в «Перечне методик, используемых для расчета, нормирования и контроля выбросов загрязняющих веществ в атмосферный воздух», утвержденного ОАО «НИИ Атмосфера».

При осуществлении намечаемой деятельности на участке открытых работ «Березовский Южный» (вторая очередь) ООО «Разрез «Березовский» выделено 13 источников загрязнения атмосферы, из них все являются неорганизованными. При этом в атмосферный воздух поступает 13 загрязняющих веществ, их них 4 обладают эффектом суммарного вредного воздействия.

Перечень и суммарный выброс загрязняющих веществ, поступающих в атмосферу при отработке второй очереди участка «Березовский Южный» представлен в таблице. 
Перечень загрязняющих веществ, выбрасываемых в атмосферу

\begin{tabular}{|c|c|c|c|c|c|}
\hline $\begin{array}{l}\text { Код } \\
\text { 3В }\end{array}$ & $\begin{array}{c}\text { Наименование } \\
\text { загрязняющего } \\
\text { вещества }\end{array}$ & $\begin{array}{c}\text { ПДКс.с., } \\
\text { ПДКм.р, } \\
\text { ОБУВ, } \\
\text { мг/м3 }\end{array}$ & $\begin{array}{c}\text { Класс } \\
\text { опасности }\end{array}$ & $\begin{array}{c}\text { Выброс } \\
\text { вещества, } \\
\text { г/с }\end{array}$ & $\begin{array}{l}\text { Выброс ве- } \\
\text { щества, } \\
\text { т/год, (М) }\end{array}$ \\
\hline 1 & 2 & 3 & 4 & 5 & 6 \\
\hline 0304 & $\begin{array}{l}\text { Азот (II) оксид } \\
\text { (Азота оксид) }\end{array}$ & 0,06 & 3 & 21,49948 & 32,3067 \\
\hline 0328 & Углерод (Сажа) & 0,05 & 3 & 0,58879 & 16,2694 \\
\hline 0337 & Углерод оксид & 3 & 4 & 306,2414369 & 259,5339 \\
\hline 0703 & $\begin{array}{l}\text { Бенз/a/пирен }(3,4- \\
\text { Бензпирен) }\end{array}$ & 0,000001 & 1 & 0,0000001 & 0,00000001 \\
\hline 2732 & Керосин & $* * 1,2$ & & 2,73576 & 77,0068 \\
\hline 2754 & $\begin{array}{c}\text { Углеводороды предель- } \\
\text { ные С12-С19 } \\
\text { (Алканы С12-С19pac- } \\
\text { творитель РПК- } \\
\text { 265П и др.) /в пересчете } \\
\text { на суммарный органи- } \\
\text { ческий углерод/ }\end{array}$ & $* 1$ & 4 & 0,0188 & 0,2886 \\
\hline 2908 & $\begin{array}{c}\text { Пыль неорганическая: } \\
70-20 \% \text { двуокиси } \\
\text { кремния (шамот, це- } \\
\text { мент, пыль } \\
\text { цементного производ- } \\
\text { ства - глина, } \\
\text { глинистый сланец, до- } \\
\text { менный шлак, } \\
\text { песок, клинкер, зола } \\
\text { кремнезем и др.) }\end{array}$ & 0,1 & 3 & 117,42442 & 707,72528 \\
\hline 2909 & $\begin{array}{c}\text { Пыль неорганическая: } \\
\text { ниже } 20 \% \\
\text { двуокиси кремния (до- } \\
\text { ломит, пыль } \\
\text { цементного производ- } \\
\text { ства - известняк, } \\
\text { мел, огарки, сырьевая } \\
\text { смесь, пыль } \\
\text { вращающихся печей, } \\
\text { боксит и др.) }\end{array}$ & 0,5 & 3 & 1,37340 & 9,4262 \\
\hline 3749 & Пыль каменного угля & $* * 0,1$ & & 1,82845 & 14,4118 \\
\hline \multicolumn{6}{|c|}{ Вещества, обладающие эффектом суммарного вредного воздействия } \\
\hline 0301 & $\begin{array}{l}\text { Азота диоксид (Азот } \\
\text { (IV) оксид) }\end{array}$ & 0,04 & 3 & 132,30616 & 198,8103 \\
\hline 0330 & $\begin{array}{c}\text { Сера диоксид } \\
\text { (Ангидрид сернистый) }\end{array}$ & 0,05 & 3 & 1,6012 & 46,0682 \\
\hline 0333 & Сероводород & $* 0,008$ & 2 & 0,0000528 & 0,00081 \\
\hline 1325 & Формальдегид & 0,01 & 2 & 0,00102 & 0,0001 \\
\hline & ИТОГО : & & & & 1361,8481 \\
\hline
\end{tabular}


Расчеты рассеивания вредных (загрязняющих) веществ в атмосферном воздухе выполнены с использованием унифицированной программы расчета загрязнения атмосферы (УПРЗА) «ЭРА-Воздух» версия 2.0, разработанной на основе методики ОНД-86 и согласованного с ГУ «ГГО им. Воейкова». Расчет осуществлен автоматическим поиском опасного направления ветра и скорости для определения максимально возможных приземных концентраций по всем загрязняющим веществам и группам суммации веществ однонаправленного воздействия с учетом фонового загрязнения атмосферы

Расчетный прямоугольник имеет стороны 60007950 м, шаг расчетной сетки 150 м. Ось «Ү» совпадает с направлением на север. В течение года преобладают ветры южного $(24,8 \%)$ и юго-западного $(21,4 \%)$ направлений.

Роза преобладающих ветров на местности ориентирована на территорию села Березово. Расчеты рассеивания загрязняющих веществ проведены по расчетному прямоугольнику, границе расчетной санитарно-защитной зоны и по территории ближайшей жилой застройки (село Березово, пос. Новый Путь и пос. Новорождественское), в том числе группе расчетных точек (№1-6).

Содержание вредных веществ в почвах на окружающих территориях, где земли относятся к категории земель сельскохозяйственного назначения, содержание вредных веществ не превышает ПДК (предельно допустимые концентрации).

\section{Заключение}

Результаты расчетов показали, что на границе санитарно-защитной зоны и на территории жилой застройки (с. Березово, пос. Новый Путь и пос. Новорождественское) превышений ПДК не наблюдается ни по одному из выбрасываемых загрязняющих веществ, в том числе ни по одной группе суммации однонаправленного действия.

Так как расчетные значения выбросов с учетом фона не превышают гигиенических нормативов качества атмосферного воздуха по всем ингредиентам следовательно, содержание вредных веществ в почвах окружающих предприятие земель сельскохозяйственного назначения не превышает ПДК, влияние на окружающую среду деятельности предприятия на период строительства можно считать допустимым.

\section{БИБЛИОГРАФИЧЕСКИЙ СПИСОК}

1. Федеральный закон РФ от 10.01.2002 г. № 7-Ф3 «Об охране окружающей среды».

2. Федеральный закон РФ от 04.05.1999 г. № 96-ФЗ «Об охране атмосферного воздуха».

3. Федеральный закон от 30.03.1999 г. № 52-Ф3 «О санитарно-эпидемиологическом благополучии населения».

4. Приказ Министерства охраны окружающей среды и природных ресурсов РФ и Комитета РФ по земельным ресурсам и землеустройству от 22.12.1995 № 525/67 «Основные положения о рекультивации земель, снятии, сохранении и рациональном использовании плодородного слоя почвы».

5. Технический проект разработки месторождения запасов угля открытым способом в лицензионных границах участка «Березовский Южный» ООО «Разрез «Березовский» (вторая очередь).

(C) A. А. Пичугова, 2021 